\title{
Streptokinase resistance: when might streptokinase administration be ineffective?
}

\author{
Maurice B Buchalter, Ganesh Suntharalingam, Ian Jennings, Catherine Hart, \\ Roger J Luddington, Ronjon Chakraverty, S Kim Jacobson, Peter L Weissberg, \\ Trevor P Baglin
}

\begin{abstract}
Objective-(a) To develop an assay for streptokinase resistance. (b) To determine the prevalence of streptokinase resistance in patients presenting with acute myocardial infarction for the first time. (c) To determine the prevalence of streptokinase resistance in patients after exposure to streptokinase or streptococcal infection.

Design-Open, prospective.

Patients-30 healthy volunteers. 40 patients admitted to the coronary care unit at Addenbrooke's Hospital with suspected acute myocardial infarction, 12 patients 12 months after streptokinase treatment, eight patients 24 months after streptokinase treatment, and sera from 12 patients with raised antistreptolysin O (ASO) titres.
\end{abstract}

Methods-Three assays were used; a dilution neutralisation assay, an enzyme linked immunosorbent assay (ELISA) for immunoglobulin G (IgG) antistreptokinase antibodies, and an in vitro fibrin plate lysis assay. All measurements were performed on venous blood samples.

Results-Neutralisation and IgG antibody titres were positively correlated. Mean (SEM) antistreptokinase concentrations in the $\mathbf{3 0}$ controls were 87 (10) $\mathrm{U} / \mathrm{ml}$ (neutralisation assay) and $28(6 \cdot 3) \mathrm{U} / \mathrm{ml}$ (ELISA). Corresponding concentrations in patients before streptokinase were $68(6 \cdot 1) \mathrm{U} / \mathrm{ml}$ and 18 (4.5) $\mathrm{U} / \mathrm{ml}$ with a mean fibrin plate assay $117(7 \cdot 1) \%$ that of controls. Resistance to streptokinase was detectable in one patient after 72 hours and in all patients by day 10 . By day 10 concentrations were $4388(919) \mathrm{U} / \mathrm{ml}, 773(109) \mathrm{U} / \mathrm{ml}$, and 17 $(5 \cdot 4) \%$. At both 12 and 24 months resistance was present in $75 \%$ of patients. Similarly $66 \%$ of high ASO titre sera showed resistance. The fibrin plate lysis assay detected significantly reduced streptokinase dependent fibrinolysis in vitro in the absence of raised total concentrations of antistreptokinase antibodies.

Conclusions-The prevalence of streptokinase resistance in patients presenting with their first myocardial infarction is low. Resistance develops early after treatment and is still present in $75 \%$ of patients after 24 months. Retreatment with streptokinase is likely to be suboptimal even after 24 months. The fibrin plate lysis assay detects resistance in patients with normal concentrations of streptokinase antibodies. Streptococcal infection is associated with a high incidence of streptokinase resistance.

\section{(Br Heart J 1992;68:449-53)}

Thrombolysis has become an essential component of the management of an acute myocardial infarction. Large controlled trials have shown that streptokinase compares favourably with other fibrinolytic agents in terms of efficacy, side effects, and cost. ${ }^{1-5}$ It is therefore likely to remain the thrombolytic agent of choice in the United Kingdom for the foreseeable future. Because of its antigenic nature, however, the presence of neutralising antibodies in some patients may reduce its effectiveness. Rapid development of immunoglobulin G (IgG) antibodies to streptokinase has been reported, ${ }^{6}$ and antibodies have been detected up to eight months after treatment.? Current recommendations advise against retreatment with streptokinase within six months and immediately after a streptococcal infection. $^{89}$ The prevalence of antistreptokinase antibodies in the general population and in patients presenting to the coronary care unit for the first time is unknown, and their potential to neutralise a standard dose of streptokinase has not been rigorously evaluated.

To test whether the development of antibodies is associated with significant streptokinase resistance we have developed an in vitro fibrin plate lysis assay and correlated this with both functional and immunological concentrations of streptokinase antibodies. A normal range for neutralising activity was established in a group of normal subjects. Patients admitted to a coronary care unit with suspected myocardial infarction were investigated on arrival and, to determine how soon and for how long neutralising activity was present, blood samples were taken early (three to ten days) and late (12 and 24 months) after streptokinase treatment. We also tested sera from patients with raised antistreptolysin $\mathrm{O}$ (ASO) titres for streptokinase neutralising activity to confirm whether recent streptococcal infection precluded administration of streptokinase. 


\section{Patients and methods}

\section{PATIENTS AND CONTROLS}

Over a six week period, venous blood samples were taken before administration of streptokinase, from 40 patients admitted to the coronary care unit of Addenbrooke's Hospital for the first time with a suspected acute myocardial infarction. Further samples were taken on days three to four and on the day of discharge (days seven to 10 ) from 15 patients who had received 1.5 million units of intravenous streptokinase (Streptase, Hoechst). None of the patients had previously received streptokinase. Venous blood was also taken from (a) 12 patients who had received streptokinase 12 months previously, (b) eight patients who had received streptokinase 24 months previously, (c) 12 patients with raised antistreptolysin $\mathrm{O}$ titres, (d) 30 healthy normal controls with no documented history of streptococcal infection. All patients gave informed verbal consent, and the study was approved by the local ethics committee.

MEASUREMENT OF STREPTOCOCCAL ANTIBODIES Immunoglobulin $\mathrm{G}$ antibodies to streptokinase were measured by an enzyme linked immunosorbent assay (ELISA) incorporating solid phase streptokinase. Neutralising antibodies were measured by a dilutional clot lysis assay.

(a) ELISA assay: $100 \mu \mathrm{l}$ of $1000 \mathrm{U} / \mathrm{ml}$ streptokinase (Streptase, Hoechst) was added to the wells of a microtitre plate (Nunc, Denmark). Plates were sealed, incubated overnight at room temperature, and washed three times in $0.01 \mathrm{~mol} / 1$ phosphate buffered saline (PBS) and $0.5 \mathrm{ml} / 1$ Tween. One hundred $\mu \mathrm{l}$ of plasma, diluted one in 40 with phosphate buffered saline (PBS) $/ 0 \cdot 1 \%$ bovine serum albumin, was then added to each well and incubated for two hours at room temperature. After three washes the wells were incubated with $100 \mu \mathrm{l}$ peroxidase-conjugated rabbit antihuman IgG (Dako) diluted $1 / 5000$ in PBS/ Tween for two hours at room temperature. After washing, $100 \mu \mathrm{l}$ substrate solution $(3 \mathrm{mg} /$ $\mathrm{ml}$ orthophenylenediamine in $0.01 \mathrm{~mol} / 1$ citrate phosphate buffer, with $0.01 \%$ hydrogen peroxide was added and the reaction stopped by the addition of $150 \mu \mathrm{l}$ sulphuric acid. Absorbance at $492 \mathrm{~nm}$ was read with a Titertek Multiscan plate reader. A standard curve was derived from doubling dilutions of normal plasma from $1 / 20$, assigned $100 \mathrm{U} / \mathrm{ml}$ and patient samples were sufficiently diluted to enable a concentration of antibody to be found from the standard curve. The concentration of antibody in the patient sample was then multiplied by the appropriate dilution factor. A concentration $>2$ SDs above the mean of the normal controls was defined as raised.

(b) Neutralisation assay: streptokinase neutralising activity was measured by a method similar to that previously reported. ${ }^{7}$ Streptokinase was diluted in saline to give a range of concentrations from $500 \mathrm{U} / \mathrm{ml}$ to $2000 \mathrm{U} / \mathrm{ml}$. Twenty $\mu$ l of each dilution was added to $200 \mu \mathrm{l}$ plasma and a fibrin clot formed by the addition of $1 \mathrm{U}$ bovine thrombin (Diagen). The highest concentration of streptokinase that failed to lyse the clot was used to calculate the streptokinase neutralising titre. Patient samples were diluted in normal plasma until clot lysis was achieved. The neutralising activity $(\mathrm{U} / \mathrm{ml})$ was calculated as:- highest concentration of streptokinase failing to lyse clot $x$ dilution of test plasma in normal plasma/10. A concentration $>2$ SDs above the mean of the normal controls was defined as raised.

\section{FIBRIN PLATE LYSIS ASSAY}

Fibrinogen (Diagen) was dissolved in imidazole buffer to a concentration of $650 \mathrm{mg} / \mathrm{l}$. Fibrin plates were prepared by clotting $10 \mathrm{ml}$ fibrinogen solution with $10 \mathrm{U}$ bovine thrombin (Diagen) and $25 \mathrm{mM}$ calcium chloride in petri dishes (Sterilin). Streptokinase was added to the plasma samples to achieve a concentration of $625 \mathrm{U} / \mathrm{ml}$. This was the calculated plasma concentrations of streptokinase that would result from a dose of 1.5 million units to a $70 \mathrm{~kg}$ subject with a packed cell volume of $45 \%$. Twenty five $\mu \mathrm{l}$ of each plasma sample were placed on a fibrin plate and incubated at $37^{\circ} \mathrm{C}$ for 24 hours. The area of lysis was calculated as the product of two diameters at $90^{\circ}$ to each other. The mean area of lysis of the 30 normal controls was $1394 \mathrm{~mm}^{2}$. All areas of lysis caused by patients plasma with added streptokinase were then reported as percentages of this value. A reduction in streptokinase dependent in vitro fibrinolysis $>2$ SDs below the mean normal activity was regarded as abnormal.

\section{ASO TITRES}

Titres of ASO were measured by a standard sheep red cell haemolysin assay (Wellcome Diagnostics).

\section{STATISTICAL ANALYSIS}

Comparisons between study groups and the normal controls were performed with the Wilcoxon's ranking test for unpaired data (MannWhitney test). The same test was used for comparisons in the group tested on several days as the numbers tested on each day varied.

\section{Results}

The mean age of the 40 patients ( 28 men) admitted to the coronary care unit was 58 (range 38-71) years. All patients received 1.5 million units of streptokinase by a one hour intravenous infusion. None of the patients suffered an allergic reaction. Venous blood samples were taken from 15 patients on day 3 and on the day of discharge (days $7 / 8$ in seven patients and days $9 / 10$ in eight patients).

The ELISA assay and the neutralisation titre assay produced comparable results and were positively correlated $(r=0.55 ; \mathrm{p}<0.001)$. Overall neither assay was correlated with the fibrin plate lysis assay. Between days 1 and 10 after streptokinase, however, a reduction (more than 2 SD below mean normal) in fibrin plate lysis was associated with antistreptokinase IgG concentrations above $155 \mathrm{U} / \mathrm{ml}$ and a neutralisation titre above $375 \mathrm{U} / \mathrm{ml}$. The table shows the normal ranges and the concentrations found in each patient group for each assay. 
Mean (SEM) in each study group for each assay

\begin{tabular}{|c|c|c|c|c|c|c|c|c|c|}
\hline \multirow[b]{2}{*}{ Method } & \multirow{2}{*}{$\begin{array}{l}\text { Normal } \\
\text { controls } \\
(n=30)\end{array}$} & \multirow{2}{*}{$\begin{array}{l}\text { Admitted } \\
\text { patients } \\
(n=40)\end{array}$} & \multicolumn{4}{|c|}{ Serial values in treated patients $(n=15)$} & \multirow{2}{*}{$\begin{array}{l}\text { Patients } \\
\text { at } 12 \\
\text { months } \\
(n=12)\end{array}$} & \multirow{2}{*}{$\begin{array}{l}\text { Patients } \\
\text { at } 24 \\
\text { months } \\
(n=8)\end{array}$} & \multirow{2}{*}{$\begin{array}{l}\text { High } A S C \\
\text { titre sera } \\
(n=12)\end{array}$} \\
\hline & & & $\begin{array}{l}\text { Day 0 } \\
(n=15)\end{array}$ & $\begin{array}{l}\text { Day 3/4 } \\
(n=15)\end{array}$ & $\begin{array}{l}\text { Day } 7 / 8 \\
(n=7)\end{array}$ & $\begin{array}{l}\text { Day } 9 / 10 \\
(n=8)\end{array}$ & & & \\
\hline $\begin{array}{l}\text { Neutralising titre } \\
(\mathrm{U} / \mathrm{ml})\end{array}$ & $\begin{array}{l}87 \\
(10 \cdot 0)\end{array}$ & - & $\begin{array}{c}68 \\
(6 \cdot 1)\end{array}$ & $\begin{array}{l}375^{\star \star \star} \\
(127)\end{array}$ & $\begin{array}{l}2053^{\star \star \star} \\
(818)\end{array}$ & $\begin{array}{l}4388^{\star \star \star} \\
(919)\end{array}$ & $\begin{array}{l}150 \star \star \star \\
(32 \cdot 3)\end{array}$ & 一 & 一 \\
\hline $\begin{array}{l}\text { ELISA IgG } \\
\text { antistreptokinase } \\
(\mathrm{U} / \mathrm{ml})\end{array}$ & $\begin{array}{c}28 \\
(6 \cdot 3)\end{array}$ & $\begin{array}{l}17 \\
(3 \cdot 4)\end{array}$ & $\begin{array}{c}18 \\
(4 \cdot 5)\end{array}$ & $\begin{array}{c}38 \\
(30 \cdot 7)\end{array}$ & $\begin{array}{l}311^{\star \star \star} \\
(133)^{-}\end{array}$ & $\begin{array}{l}773^{\star \star \star} \\
(109)\end{array}$ & $\begin{array}{l}120^{\star \star \star} \\
(24 \cdot 9)\end{array}$ & $\begin{array}{l}140 \star \star \star \\
(27 \cdot 6)\end{array}$ & $\begin{array}{l}177^{\star \star} \\
(44 \cdot 3)\end{array}$ \\
\hline $\begin{array}{l}\text { Fibrin plate lysis } \\
\text { assay as } \% \text { of mean normal }\end{array}$ & $\begin{array}{l}100 \% \\
(4 \cdot 0 \%)\end{array}$ & - & $\begin{array}{l}117 \% \\
(7 \cdot 1 \%)\end{array}$ & $\begin{array}{l}108 \% \\
(14 \cdot 1 \%)\end{array}$ & $\begin{array}{c}34 \% \star \star \star \star \\
(15 \cdot 6 \%)\end{array}$ & $\begin{array}{l}17 \% \%^{\star \star \star} \\
(5 \cdot 4 \%)\end{array}$ & $\begin{array}{l}43 \% \star \star \star \\
(9 \cdot 7 \%)\end{array}$ & $\begin{array}{l}40 \%{ }^{\star \star} \\
(9 \cdot 1 \%)\end{array}$ & $\begin{array}{l}50 \% \%^{\star \star} \\
(10 \cdot 1 \%)\end{array}$ \\
\hline
\end{tabular}

${ }^{\star \star} \mathrm{p}<0.01 ;{ }^{\star \star \star} \mathrm{p}<0.001$.

Fibrin plate lysis in the 30 normal controls (mean age 49, range 34-64 years, 10 women) in the absence of streptokinase was less than $2 \%$ of that in the presence of streptokinase.

None of the patients admitted to the coronary care unit had raised concentrations of IgG antistreptokinase antibodies on admission. In 15 of these patients neutralisation titres and fibrin plate lysis values were also measured. None had evidence of either neutralising antibodies or impaired in vitro fibrinolytic responses to streptokinase.

By days 3/4 $(n=15)$ the neutralising titre had risen above the normal range ( $>2$ SDs above the mean) in nine patients (range 200 to $2000 \mathrm{U} / \mathrm{ml}$ ). Eight of these, however, showed no increase in antistreptokinase IgG by ELISA and no reduction in fibrinolytic activity in the fibrin plate lysis assay. One patient had a rise in neutralising titre to $2000 \mathrm{U} / \mathrm{ml}$ and an ELISA IgG of $437 \mathrm{U} / \mathrm{ml}$. This was associated with a reduction of in vitro fibrinolysis to $6 \%$ of control values.

By days $7 / 8(n=7)$ the neutralisation titre was above the normal range in all patients and IgG antibodies were above normal in all but two. Only the patients with raised IgG antibodies had significantly reduced fibrinolytic responses. By day $10(n=8)$ all patients had raised antibody concentrations by both assays with reduced fibrinolytic responses to a mean value of $17 \%$ (range $1 \%$ to $54 \%$ ) of controls. The day 7-10 results were significantly different from the normal control and day 0 results for each of the three assays ( $p<0.001$ ). Figures 1 and 2 show the IgG antistreptokinase concentrations and the fibrinolytic responses over the 10 day study period.

Of the 12 patients studied 12 months after

Figure 1

Antistreptokinase

(Anti-Sk) IgG antibody concentrations measured by ELISA over the 10 day period after 1.5 million units of intravenous streptokinase in 15 patients (all patients were tested on day 0 , days $3 / 4$ and days $7 / 10$ and many points overlap).

Horizontal line indicates mean (+2SDs) for normal control group.

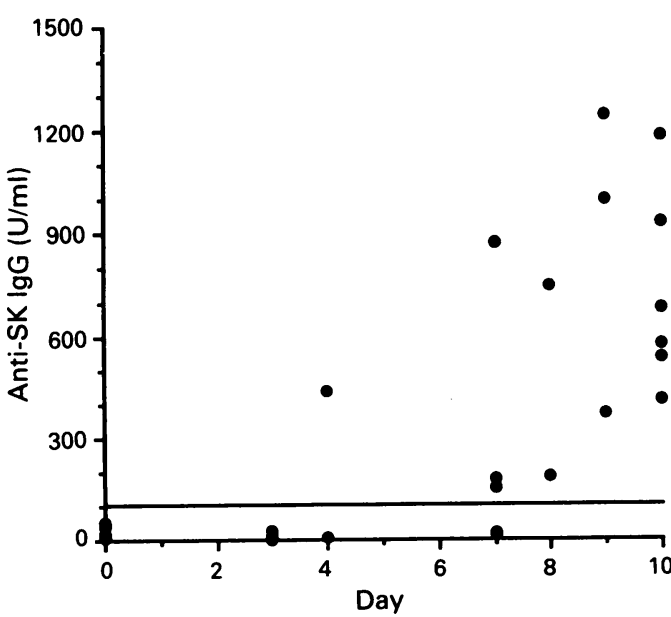

being given streptokinase (mean age 56 , range 36-70 years, two women), only three had a raised neutralisation titre, but six had raised IgG concentrations. All six of these had reduced fibrin plate lysis values (range $10 \%-35 \%$ ). An additional three patients, however, with IgG concentrations within the normal range also had impaired fibrinolysis $(10 \%, 32 \%, 38 \%)$. Only three patients had no evidence of streptokinase resistance by any method.

Of the eight patients studied at 24 months (mean age 53, range 43-62 years, two women), six had reduced fibrin plate lysis (range $3 \%-24 \%$ ). Five of these six had raised IgG concentrations.

Of the 12 sera from patients with raised ASO titres, six had raised ELISA IgG concentrations and all of these, plus two with concentrations within the normal range, had reduced fibrin plate lysis values (range $9 \%-64 \%$ ). Figure 3 shows the individual and mean fibrinolytic responses of each of the study groups.

\section{Discussion}

None of the patients admitted with acute myocardial infarction had raised concentrations of antistreptokinase antibodies or in vitro fibrinolytic resistance to streptokinase. The prevalence of antistreptokinase antibodies in patients presenting to the coronary care unit for the first time is therefore low and most should

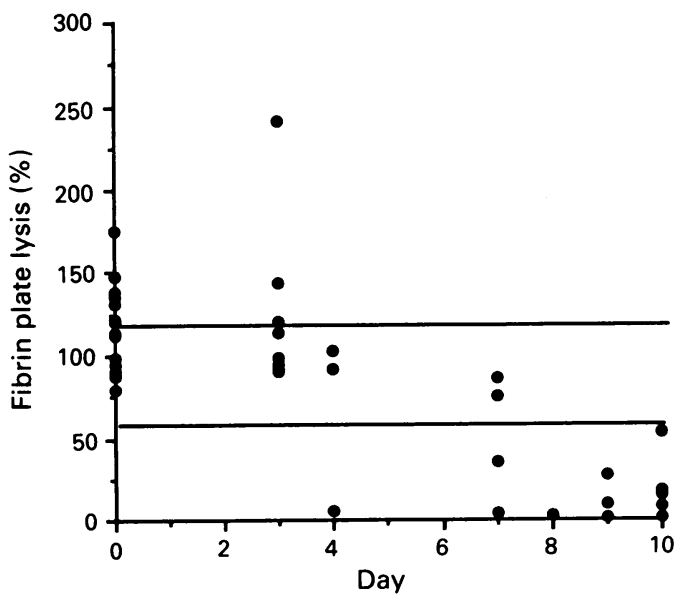

Figure 2 Fibrin plate lysis (\%) relative to mean normal result over the 10 days after 1.5 million units of intravenous streptokinase in 15 patients (all patients were tested on day 0 , days $3 / 4$ and days $7 / 10$ and many points overlap). Horizontal lines indicate mean ( $2 S D s$ ) for normal control group. 
Figure 3 Individual values (point) and mean values (bar) of fibrin plate lysis in each of the study groups. Values for many patients overlap.

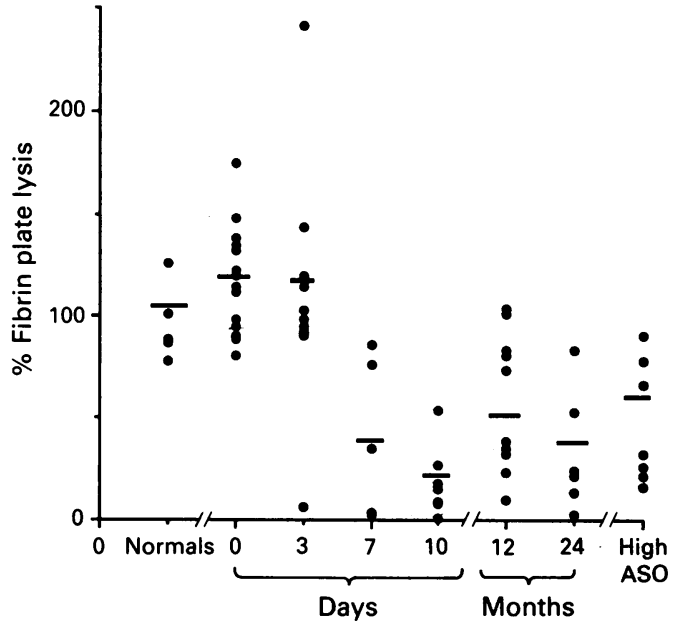

respond to a standard dose of streptokinase. This is despite the fact that many of them will have encountered streptococci in the past.

By days three to four there had been a slight increase in neutralising antibody concentrations; however, in only one patient was this substantial enough to cause a reduction in streptokinase induced fibrinolysis. Thus retreatment with streptokinase within 72 hours of the initial dose is likely to be successful in most patients but may result in impaired thrombolysis in some. By day seven most patients had streptokinase resistance and by day 10 all patients had resistance. This time course suggests a primary rather than secondary antibody response to streptokinase.

Patients studied 12 months after a dose of streptokinase had varying concentrations of antibodies. Nevertheless, nine $(75 \%)$ of them still had significantly impaired fibrin plate lysis. Of the eight patients studied at 24 months six $(75 \%)$ still had impaired fibrin plate lysis. Therefore, roughly three quarters of patients might be expected to have some degree of resistance to streptokinase, even after 12 or 24 months. Further information on the effects of streptokinase resistance on drug readministration is urgently required. Similarly, roughly two thirds of patients with serological evidence of recent streptococcal infection are likely to have impaired thrombolysis with streptokinase (eight of 12 patients). The precise temporal relation between streptococcal infection and streptokinase resistance also warrants further study.

A reduction of in vitro fibrinolysis might reasonably be expected to predict a decrease in thrombolytic activity in vivo. However, it was not possible in this study to determine to what extent the two are correlated. In the 10 days after a dose of streptokinase raised concentrations of antistreptokinase antibody measured by the neutralisation assay were not necessarily associated with reduced in vitro fibrinolysis. By contrast, a raised ELISA IgG titre was always associated with reduced fibrinolysis. In these patients an increase in IgG antibodies is likely to predict impaired thrombolysis. Serum from five patients, (three 12 months after treatment and two with a high ASO titre) however, caused reduced fibrin lysis in the absence of raised streptokinase antibodies by either assay. Thus a normal IgG concentration $>10$ days after treatment does not necessarily ensure a normal fibrinolytic response. This discrepancy between antibody concentrations and impaired fibrinolysis has not been explained. One possibility is that there is a reduction in total antibody concentrations over time but maintenance of high affinity antibodies. A study of the concentrations of antistreptokinase immunoglobulin subclasses after treatment is being undertaken to examine this phenomenon.

To understand fully the clinical relevance of reduced in vitro fibrinolysis a comparison between the measurements made in this study and a clinical marker of effective thrombolysis is needed. At present no reliable non-invasive marker exists. In a recent study, however, Massel et al showed that the thrombolysis induced by streptokinase in an external jugular vein thrombosis model in rabbits was significantly impaired by giving streptokinase to the rabbits one month previously. ${ }^{10}$ The pretreated animals had raised IgG antistreptokinase titres. This study suggests that there is a close correlation between in vitro resistance and impaired thrombolysis in vivo.

The results of our study suggest that up to $75 \%$ of patients treated once with streptokinase will be resistant to further treatment with streptokinase containing agents after two years. This suggests that the outcome from retreatment with streptokinase containing agents is likely to be unpredictable for a period beginning four to seven days after streptokinase doseage and lasting for more than two years. Other data suggest that this period may last for at least four years. ${ }^{11}$ To identify patients who would benefit from repeated treatment with streptokinase, antibody concentrations or preferably fibrin plate lysis, could be measured routinely at regular intervals after first treatment. Such information, however, would have to be available immediately on admission with a further infarct. The only way to ensure this would be for the patients to carry this information themselves. Unfortunately, none of the tests used in this study could be performed rapidly enough at the bedside to be used on admission. We believe that titrating the dose upwards on the basis of the results of an in vitro test is an impractical approach that will only increase the antigenic load and the risk of an adverse immunological reaction.

In conclusion, streptokinase is likely to remain a first line agent for thrombolytic treatment in acute myocardial infarction. The prevalence of streptokinase resistance at first presentation is low unless there is evidence of recent streptococcal infection. The best predictor of streptokinase resistance is the fibrin plate lysis assay. Resistance can develop within 72 hours, although most patients seem to have a primary antibody response developing over seven to 10 days. All patients are resistant after 10 days and roughly $75 \%$ remain resistant after 24 months. Retreatment with thrombolytic agents containing streptokinase is inadvisable 
until the full clinical relevance and time course of streptokinase resistance is established.

PLW is a British Heart Foundation Senior Research Fellow.

1 Sheehan FH, Braunwald E, Canner P, et al. The effect of intravenous thrombolytic therapy on left ventricular function: a report on tissue type plasminogen activator and streptokinase from the thrombolysis in myocardial infarction (TIMI Phase I) trial. Circulation 1987;75:817-29.

2 White HD, Rivers JT, Maslowski AH, et al. Effect of intravenous streptokinase as compared with that of tissue plasminogen activator on left ventricular function afte first myocardial infarction. N Eng J Med 1989;320:817-21

3 Gruppo Italiano per lo Studio della Sopravvivenza nell Infarto Miocardico. GISSI-2: a factorial randomised tria of alteplase versus streptokinase and heparin versus no heparin among 12,490 patients with acute myocardial infarction. Lancet 1990;336:65-71.
4 The International Study Group. In-hospital mortality and clinical course of 20,891 patients with suspected acute myocardial infarction randomised between alteplase and streptokinase with or without heparin. Lancet 1990 336:71-5.

5 The Third International Study of Infarct Survival (ISIS 3). Meeting of the American College of Cardiology. Atlanta: Am Coll Cardiol, 1991.

6 Lynch M, Littler WA, Pentecost BL, Stockley RA. Antistreptokinase titres after intravenous streptokinase (ltr). Lancet 1990;693:534.

7 Jalihal S, Morris GK. Antistreptokinase titres after intravenous streptokinase. Lancet 1990;335:184-5.

8 ABPI daus tions 676: (Data sheet Streptase)

9 ABPI data sheet compendium 1990-91. Datapharm publications 782: (Data sheet Kabikinase)

10 Massel D, Turpie AGG, Cairns JA, Ofosu FA, Buchanan MR. Previous streptokinase (SK) therapy inhibits subsequent SK thrombolysis. Circulation 1991;84:II-467.

11 Elliot JM, Cross DB, Cederholm-Williams S, White HD. Streptokinase titers 1 to 4 years after intravenous streptokinase. Circulation 1991;84:II-116. 